\title{
REMOTE SENSING MONITORING OF WETLAND OF SANYA AND LINGSHUI IN HAINAN PROVINCE, BASED ON GF DATA
}

\author{
Y. Guo ${ }^{1}$, L. Li ${ }^{1,2, *}$ \\ ${ }^{1}$ China University of Geosciences (Beijing), Beijing, China - gy939251@163.com \\ ${ }^{2}$ China Aero Geophysical Survey \& Remote Sensing Centre for Land and Resources, Beijing, China - lileey2010@163.com
}

Commission III, WG III/1

KEY WORDS: Remote Sensing, Wetland Monitoring, GF Data, Natural Wetland, Constructed Wetland, Hainan Province

\begin{abstract}
:
Wetland is an important land and natural resources with many functions. It is closely related to the survival, reproduction and development of human beings, as well as one of the most important living environments of human beings. Hainan Province, which is located in the northern edge of the tropics with the tropical monsoon climate and covers a variety of wetland types. In this paper, in order to investigate the change of wetland distribution and the variations of area in study region, the remote sensing data of GF-1 and GF-2 from 2009 to 2015 were used. The method used in this study was automatic information extraction and human-computer interaction. The wetland types in study area mainly was divided into three level-1 classes, including coastal wetland, river wetland and lake wetland, and was also divided into eight level-2 classes at the same time. The results showed that the total area of wetland increased $9.13 \mathrm{~km}^{2}$ in study area from 2009 to 2015 , in which the area of constructed wetland increased $6.29 \mathrm{~km}^{2}$, the natural wetland increased only $2.83 \mathrm{~km}^{2}$. The area of natural wetland has not changed much, but its proportion has been reduced. This reflected that the wetland in the research area has been more artificially intervened since 2009 , which caused the increasing of the area of constructed wetland. As the wetland resources can coordinate the sustainable benefit of the society, the protection of natural wetland should be strengthened and valued.
\end{abstract}

\section{INTRODUCTION}

As one of the most significant natural resource, wetland play an important role in water withdrawals, land conversion to agriculture, shoreline and waterfront development, and also a key habitat within the domestic biodiversity hotspot and provide important ecosystem services for human well-being (Craft, 2016; Perennou et al., 2018). There are different definitions about wetland. Department of Environmental Protection State of Florida Glossary defines wetland as a land area that is saturated with water, either permanently or seasonally, such that it takes on the characteristics of a distinct ecosystem. While the Ramsar Convention on Wetland, which is an international treaty signed in 1971, is aimed at international cooperation for the management and well use of wetlands resources, defines wetland as "areas of marsh, fen, peatland or water, whether natural or artificial, permanent or temporary, with water that is static or flowing, fresh, brackish or salt, including areas of marine water the depth of which at low tide does not exceed 6m" (Ramsar Convention, 1987).

There are different rules about wetland classification in different countries. The systematic classification such as the U.S. fish and wildlife service system are widely used in the United States. This classification divided wetlands into 5 systems as sea, estuaries, rivers, lakes and swamps (Cowardin, L.M., et al., 1979). The wetland classification system developed by the Canada national wetland working group divided the wetlands into 5 types. Such as bog, fen, swamp, marsh and shallow water (National Wetlands Working Group et al., 1997). Hydrological classification system of Great Lake divided wetlands into lake wetland, river wetland and barrier-protected wetland (Dennis AA, 2005a). In our country, the research about wetland classification is mainly base on regional classification system since the diversity of hydrological condition between different regions. Zou, who did research on wetlands classification divided wetland of Hainan island into coastal, river, lake and swamp, included 20 types totally (Zou et al., 1999a). Jiangsu province established coastal wetland classification system which divided wetland into coastal, rivers, pond, reservoir and estuary wetland (Zhu et al., 2007a). Fujian province divided their wetlands into offshore wetland, inland wetland and constructed wetland (Chen, 2007).

According to results of China's second national wetland resource survey, which is reported by the State Forestry Bureau of China, the total area of wetlands is $53.42 \times 10^{6}$ ha, and accounts for $5.58 \%$ of China's territorial area, with a loss rate of $9.33 \%$ compared to the first survey (Wetland China, 2014).

As China's GF series satellites successfully launched one after the other, such as GF-1 and GF-2, the GF data gradually replaced nearly $80 \%$ satellite data abroad of the same resolution (China News, 2016), and also had been widely applied in various fields.

\footnotetext{
* Corresponding author: $\mathrm{Li} \mathrm{Li}$, works in China Aero Geophysical Survey \& Remote Sensing Centre for Land and Resources. Mail: lileey2010@163.com Tel: 13810586130
} 
Many research had been carried out, such as information extraction (Zhang et al., 2017), investigating mine environment (Ma et al., 2017), monitoring wind farms (Shen et al., 2017), monitoring the agricultural (Zhou et al., 2017) and so on. Some researchers assessed the quality of the GF data, proved its superiority.

In this paper, the current status of wetlands in study area were reviewed, and the regional variation of wetlands was discussed based on the data of wetlands resource survey. The objectives of this paper are as follows: 1) review the status of wetlands in study area in 2009 and 2015,2) compare and analyze the data of wetlands area between two years, and finally 3) summarize variation tendency of wetlands in study area and discuss countermeasure for improvement.

\section{STUDY AREA AND DATA SOURCE}

The study area is located in Sanya city and Lingshui county, Hainan Province (Figure 1). It is located in the south of Hainan island, which has developed transportation. It is located between latitude $18^{\circ} 10^{\prime} \mathrm{N}$ and latitude $18^{\circ} 40 \mathrm{~N}$, and longitude from $119^{\circ} 10^{\prime} \mathrm{E}$ to $110^{\circ} 10^{\prime} \mathrm{E}$, covers approximately $1700 \mathrm{~km}^{2}$. It is a typical hilly area and mainly includes several rivers and reservoirs.

GF1, GF2 and Rapideye data were used in this study for extraction of wetlands, which were acquired in 2009 and 2015 respectively. The images covering the study area were obtained from China aero geophysical survey \& remote sensing center for land and resources.

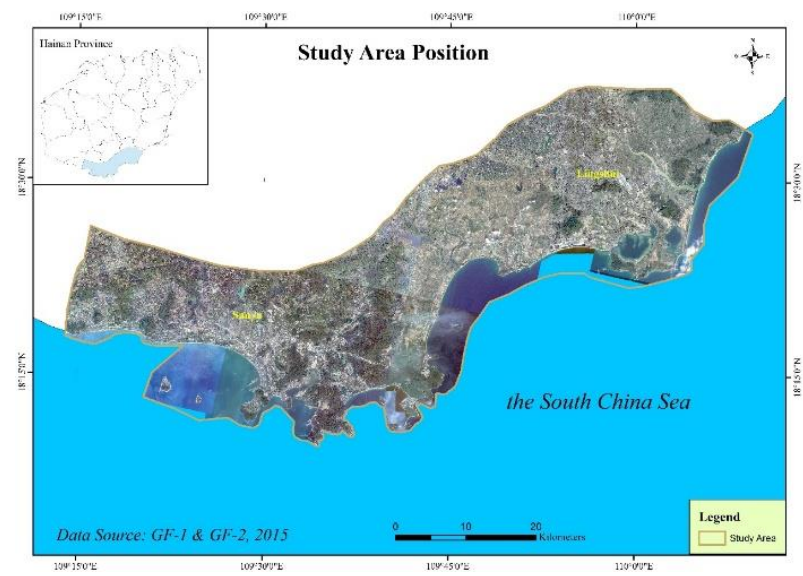

Figure 1. Remote sensing images of Study region

\section{METHOD}

\subsection{Data Preprocessing}

We used bands 3, 2, 1 for true color composite. The images were processed using ArcMap 10.2 software. These images were georeferenced to Xi' an 80 coordinate system, Zone 37 North based on 1: 50,000 scales topographic maps and enhanced using percentage truncation to highlight the surface features. And then, we clipped images into the shape of study area so that the size of data storage was deduced and easily loaded while processing. After these steps were completed, the 5 separate images were combined to produce one raster image.

\subsection{Establishing of the Classification System}

The wetland types in study area mainly was divided into three level-1 classes, including coastal wetland, river wetland and lake wetland, and was also divided into eight level-2 classes at the same time. The specific contents of each class are shown in Table 1.

\begin{tabular}{|l|l|l|}
\hline Level-1 Class & No. & Level-2 Class \\
\hline \multirow{4}{*}{ Coastal wetland } & 1 & Rocky coast \\
& 2 & Shaggy beach \\
& 3 & Mangrove swamp \\
& 4 & Estuarine waters \\
\hline \multirow{2}{*}{ River wetland } & 5 & Permanent river \\
& 6 & Intermittent river \\
\hline \multirow{3}{*}{ Lake wetland } & 7 & Permanent \\
& 8 & freshwater lake \\
& & Reservoir \\
\hline
\end{tabular}

Table 1. Classification classes of wetlands in study area.

\subsection{The Establishing of Interpretation Marks}

The most important procedure in interpretation is establishing the interpretation marks. The direct interpretive marks include colors and hue, texture, shape, size, position, pattern, shadow and so on. Sometimes, we could use one or two marks to recognize surface features, but usually, it's kind of hard to verify through single mark because of complicated circumstance. Therefore, it's necessary to synthesize several marks to achieve interpreting accurately.

The composition of wetlands is mostly water. The water bodies were shown as blue or black in the true color composite images due to the impact of sediment concentration. And then, we would distinguish kinds of wetlands by their shapes and position. Rocky coast and shaggy beach were along the coastline, the former was shown as gray-white irregular blocks, while the latter was shown as white stripe with delicate texture. Mangrove swamp was tropical and subtropical coastal marshes formed by mangrove communities, where near the estuary and bay. It was shown as dark blue with dark green clumps on it. Estuarine water was easily to distinguish from the images due to its typical position. Permanent river was shown as blue irregular stripe, while intermittent rive was quite the opposite, it was shown as polyline. Permanent freshwater lake was usually shown as a big blue patch, and when the edge of the side was a smooth line, that meant it was a reservoir

\subsection{Extraction of Wetland Information Based on GF Data}

After the previous preparation, the following procedures were adopted to extract the information for the wetlands in study area. And in this part, ArcMap 10.2 software was used for processing and extracting, combined with above classifying rules. Attribute tables would be completed after these polygons represented wetlands in study area were extracted. In the table, type, description and year of wetland would be filled in, so that we could analyze and make comparison with data in 2009 and 2015.

\section{RESULT AND DISCUSSION}

The area extent of wetlands in square kilometer and area coverage in percent for the two periods is shown in Table 2. And the area change is shown in Figure 2, Figure 3. The total area of wetlands is estimated as $97.62 \mathrm{~km}^{2}$ in 2009 and $106.75 \mathrm{~km}^{2}$ in 
2015 , with a growth of $9.13 \mathrm{~km}^{2}$. In order to analyze the change of area about each type of wetlands, we decided to divide eight kinds of wetlands into two parts: natural wetland and constructed wetland. The former included coastal wetlands (rocky coast, shaggy beach, mangrove swamp and estuarine waters), permanent river and permanent freshwater lake. And the latter included intermittent river and reservoir.

\begin{tabular}{|c|c|c|c|c|c|c|c|}
\hline \multirow[b]{2}{*}{$\begin{array}{l}\mathrm{N} \\
\mathrm{O}\end{array}$} & \multirow[b]{2}{*}{$\begin{array}{l}\text { Wetland } \\
\text { types }\end{array}$} & \multicolumn{2}{|l|}{2009} & \multicolumn{2}{|l|}{2015} & \multirow{2}{*}{$\begin{array}{l}\text { Are } \\
\mathrm{a} \text { in } \\
\text { cha } \\
\text { nge } \\
\mathrm{s} \\
*(\mathrm{k} \\
\left.\mathrm{m}^{2}\right)\end{array}$} & \multirow{2}{*}{$\begin{array}{l}\% \\
\text { of } \\
\text { area } \\
\text { in } \\
\text { cha } \\
\text { nge } \\
\text { s }\end{array}$} \\
\hline & & $\begin{array}{l}\text { Area } \\
\left(\mathrm{km}^{2}\right. \\
)\end{array}$ & $\begin{array}{l}\% \text { of } \\
\text { distr } \\
\text { ibuti } \\
\text { on }\end{array}$ & $\begin{array}{l}\text { Area } \\
\left(\mathrm{km}^{2}\right. \\
)\end{array}$ & $\begin{array}{l}\% \\
\text { of } \\
\text { distr } \\
\text { ibuti } \\
\text { on }\end{array}$ & & \\
\hline 1 & $\begin{array}{l}\text { Rocky } \\
\text { coast }\end{array}$ & 2.47 & 2.53 & 2.21 & 2.07 & $\overline{0}-26$ & - \\
\hline 2 & $\begin{array}{l}\text { Shaggy } \\
\text { beach }\end{array}$ & 8.46 & 8.67 & 6.45 & 6.04 & $\begin{array}{l}- \\
2.01\end{array}$ & $\begin{array}{l}- \\
2.6 \\
3\end{array}$ \\
\hline 3 & $\begin{array}{l}\text { Mangrove } \\
\text { swamp }\end{array}$ & 0.57 & 0.58 & 0.66 & 0.62 & 0.09 & $\begin{array}{l}0.0 \\
4\end{array}$ \\
\hline 4 & $\begin{array}{l}\text { Estuarine } \\
\text { waters }\end{array}$ & $\begin{array}{l}38.0 \\
6\end{array}$ & $\begin{array}{l}38.9 \\
9\end{array}$ & $\begin{array}{l}38.3 \\
2\end{array}$ & $\begin{array}{l}35.8 \\
9\end{array}$ & 0.26 & -3.1 \\
\hline 5 & $\begin{array}{l}\text { Permanent } \\
\text { river }\end{array}$ & $\begin{array}{l}14.8 \\
1\end{array}$ & $\begin{array}{l}15.1 \\
7\end{array}$ & 18.2 & $\begin{array}{l}17.0 \\
5\end{array}$ & 3.39 & $\begin{array}{l}1.8 \\
8\end{array}$ \\
\hline 6 & $\begin{array}{l}\text { Intermitte } \\
\text { nt river }\end{array}$ & 0.23 & 0.23 & 0.14 & 0.13 & $\begin{array}{l}- \\
0.09\end{array}$ & -0.1 \\
\hline 7 & $\begin{array}{l}\text { Permanent } \\
\text { freshwater } \\
\text { lake }\end{array}$ & 4.4 & 4.51 & 5.86 & 5.5 & 1.46 & $\begin{array}{l}0.9 \\
9\end{array}$ \\
\hline 8 & Reservoir & $\begin{array}{l}28.6 \\
2\end{array}$ & $\begin{array}{l}29.3 \\
2\end{array}$ & $\begin{array}{l}34.9 \\
1\end{array}$ & 32.7 & 6.29 & $\begin{array}{l}3.3 \\
8\end{array}$ \\
\hline & Total & $\begin{array}{l}97.6 \\
2\end{array}$ & & $\begin{array}{l}106 . \\
75\end{array}$ & & 9.13 & \\
\hline
\end{tabular}

Table 2. Area and Amount of Change in Different Wetlands in the Study Area During 2000-2011.

(* Negative value refers to decrease of area and positive value refers to increase of area)

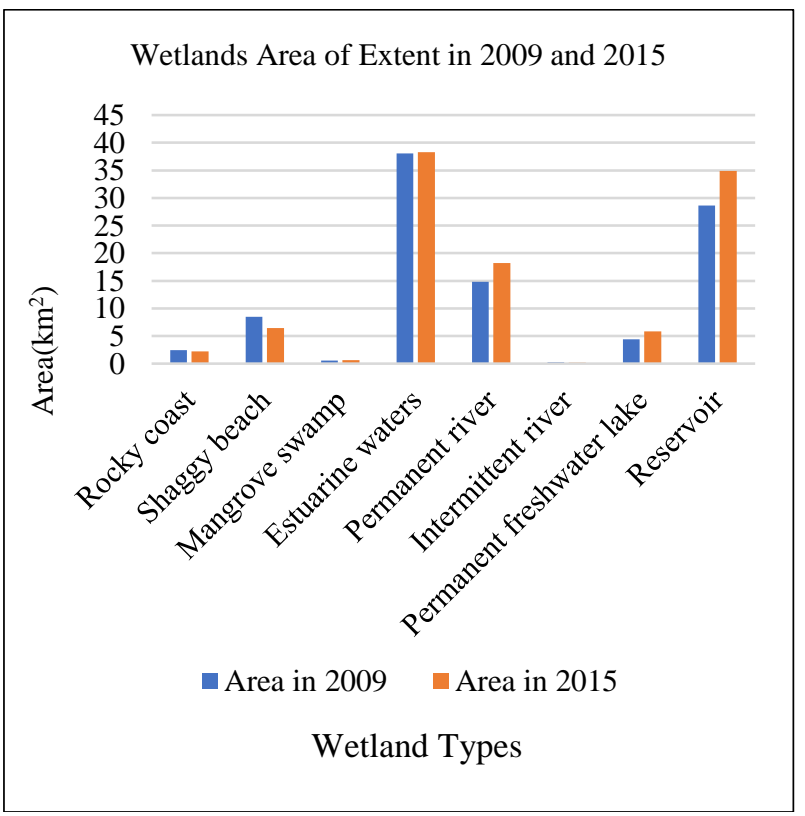

Figure 2. Changes in Area of Wetland in the Study Region During 2009 2015

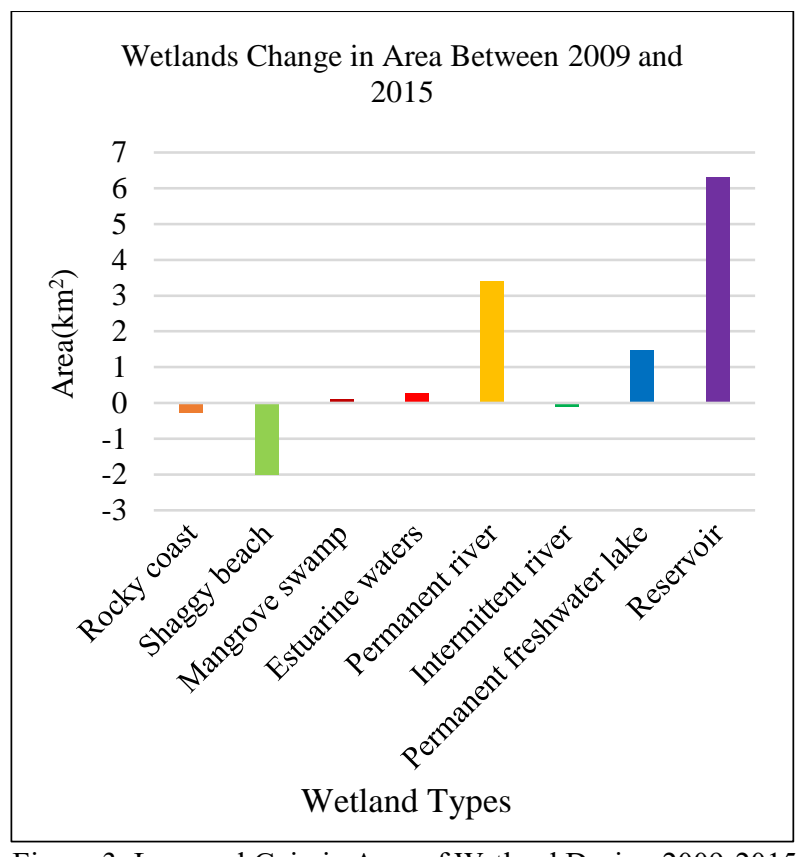

Figure 3. Loss and Gain in Area of Wetland During 2009-2015

\subsection{Natural Wetland}

As Table 3 and Figure 2 \& Figure 3 show, during this period (2009-2015), rocky coast is reduced in the study area from 2.47 $\mathrm{km}^{2}$ to $2.21 \mathrm{~km}^{2}$, with a loss of $0.26 \mathrm{~km}^{2}$; shaggy beach shows a significant decreasing trend from $8.46 \mathrm{~km}^{2}$ to $6.45 \mathrm{~km}^{2}$, with a loss of $2.01 \mathrm{~km}^{2}$. A reduction of area in rocky coast and shaggy beach means the decreasing of seaside space, where ports and wharfs had been constructed these years, as well as facilities for recreation (Liang et al., 2015a). Mangrove swamp is raised from $0.57 \mathrm{~km}^{2}$ to $0.66 \mathrm{~km}^{2}$, shows a little increasing. The mangrove vegetation in study area are located on the banks of Qingmei Port, Iron-Stove Port, Yulin Port and estuary of Sanya River. During the period, mangrove resource has been protected all the time (Yang et al., 2012a). Both permanent river and freshwater lake raise in area as $3.39 \mathrm{~km}^{2}$ and $1.46 \mathrm{~km}^{2}$ respectively, it is probably because the State Council issued relevant policies since 2010, strengthening ecology environment protection construction (Ye et al., 2016a). And estuarine waters is estimated as $38.06 \mathrm{~km}^{2}$ in 2009 and increase to $38.32 \mathrm{~km}^{2}$ in 2015. And in 2016, China State Council released the scheme for wetland conservation and rehabilitation system (Cui et al., 2017a); and in 2017, National wetland protection plan for the 13th five-year plan was issued (State Forestry Bureau, 2017). It is announced that the national total area of wetland should not less than 800 million a, and wetland protection rate would be more than $50 \%$. It is estimated that the area of restoring degraded wetland would be $1.4 \times 10^{4}$ ha, and the area of new wetland would be $2 \times 10^{5}$ ha by 2020 .

\subsection{Constructed wetland}

In this paper, intermittent river means irrigation canal and ditch. During the period, intermittent river is reduced from $0.23 \mathrm{~km}^{2}$ to $0.14 \mathrm{~km}^{2}$ with a total loss in area as $0.09 \mathrm{~km}^{2}$. However, reservoirs in the study region shows a significant increasing in area as $6.29 \mathrm{~km}^{2}$, with a growth rate of $3.38 \%$. it is reflected that more and more reservoirs and the pit ponds were constructed, in other words, the wetland in the research area has been more artificially intervened since 2009. On the one hand, the urbanization has accelerated the development of the tourism 
industry in Hainan, and on the other hand, it has raised the demand for artificial wetlands (Zhou et al., 2015a).

\section{CONCLUSION}

Decadal changes of area in wetland reflect the economic development conditions in the area and indicating the nature's vulnerability due to human activities. GIS and remote sensing provides an effective method for monitoring wetland changes in area.

Firstly, on the one hand, it is evidently noticed that total area of wetland had an increasing in the study area $\left(9.13 \mathrm{~km}^{2}\right)$, in which reservoirs raised the most $\left(6.29 \mathrm{~km}^{2}\right)$. On the other hand, the natural wetland had also been slow to grow due to varying degrees of protection $\left(2.93 \mathrm{~km}^{2}\right)$.

Secondly, among the six kinds of natural wetlands, shaggy beach reduced the most in area as $2.01 \mathrm{~km}^{2}$. The reducing part was probably used in the construction of artificial port. However, with the shipping industry and tourism development gradually saturated, this phenomenon would be temporary. In the future, more systems of wetland protection would come out for sustainable development.

And last, wetland is a complex integrated ecosystem, which requires comprehensive management measures to manage the integrity or watershed of wetland ecosystem. We will speed up the construction of ecological civilization system, create special ecological zones, optimize the utilization of wetland resources, and implement the red line of ecological protection, so as to ensure the healthy and strong protection of the ecological system of wetland in Hainan.

\section{REFERENCES}

Chen, Q., 2007, Study on Wetland Types and their Distribution in Fujian Based on 3S Technologies. Fujian Normal University, Fuzhou, China.

http://kreader.cnki.net/Kreader/CatalogViewPage.aspx?dbCode $=$ cdmd\&filename $=2007186165$. $n$ h \& tablename $=$ CMFD2007\&c ompose $=\&$ first $=1 \&$ uid $=$

China forestry network, 2018, National wetland protection plan for the 13th five-year plan.

http://sdzg.forestry.gov.cn/portal/sdzg/s/2977/content1066955.html.

Chinanews.com. 2016. High-resolution data replaces $80 \%$ of foreign satellite data. Spacecraft Recovery \& Remote Sensing, 37(1), pp. 31

Convention on Wetlands of International Importance especially as Waterfowl Habitat, 1987. http://ramsar.rgis.ch/cda/en/ramsardocuments-texts-convention-on/main/ramsar/1-31-

$38 \% 5$ E20671 $4000 \quad 0$

Cowardin, L. M., Carter, V., Golet, E. C., et al. 1979. Classification of wetlands and deep-water habitats of the United States. Report, US Fish and Wildlife Service FWS/OBS, Washington D C.

Craft, C., 2016. Creating and Restoring Wetlands, pp.327-340, https://doi.org/10.1016/B978-0-12-407232-9.00013-0.
Cui, L. J., Xiaodong, Z., Manyin, Z.,2017a. The Tasks and perspectives of wetland conservation and management in China. Environmental Protection, 45(4), pp.13-17.

Dennis, A. A., Douglas, A. W., Joel, W. I., et al., 2005a. Hydrogeomorphic Classification for Great Lakes Coastal Wetlands. Journal of Great Lakes Type Research, 31(s1), pp. 129-146.

Liang, C., Lei, H., Xuesong, C., et al., 2015a, Study on the change of coastline in sanya in recent 5 years. Ocean Development and Management, 5, pp. 43-45.

Ma, X. Q., Peng, L., Xu, S. N., et al., 2017a, Application of GF2 satellite data to mine geological environment investigation in Daye, Hubei Province. REMOTE SENSING FOR LAND \& RESOURCES, 29(s1), pp. 127-131.

National Wetlands Working Group, Warner, B. G., Rubec, C. D. A, 1997. The Canadian Wetland Classification System, Second Edition. Report, Wetlands Research Centre, University of Waterloo, Waterloo, Ontario.

Perennou, C., 2018. Advances in Ecological Research, Vol.58, pp. 243-277,

http://doi.org/10.1016/bs.aecr.2017.12.002.

Shen, G., Bin, X., Yunxiang, L., et al., 2017a, Monitoring wind farms occupying grasslands based on remote-sensing data from China's GF-2 HD satellite--A case study of Jiuquan city, Gansu province, China. Resources, Conservation and Recycling, 121, pp. 128-136.

Yang, F., Chuanjin, Y., Ning, S., et al., 2012a, Landscape Features and Its Protection and Utilization of Mangrove Forest in Sanya. CENTRAL SOUTH FOREST INVENTORY AND PLANNING, 31(2), pp. 31-34.

Ye, P., Huihui, Y., Fengxia, W., 2016a. Ecosystem service values based on the land use and land cover change in Sanya. Natural Science Journal of Hainan University, 34(1), pp. 51-58.

Zhang, Y., Mingchang, S., Xin, Z., et al., 2017a, Methods for automatic identification and extraction of terraces from high spatial resolution satellite data (China-GF-1). International Soil and Water Conservation Research, pp. 17-25.

Zhou, M. Y., Yaobin, S., Wenbing, L., et al., 2015a, On the Protection and Threat Factors for Wetlands in Hainan. Journal of Hangzhou Normal University (Natural Science Edition), 14(6), pp. 602-607.

Zhou, Q. B., Qiangyi, Y., Jia, L., Wenbin, W., Huajun, T., 2017a, Perspective of Chinese GF-1 high-resolution satellite data in agricultural remote sensing monitoring. Journal of Integrative Agriculture, 16(2), pp.242-251.

Zhu, Y. F., Zejian, C., 2007a, Wetland Classification in Jiangsu Coastal Zone Based on RS and GIS. Journal of Geology, 31(3), pp. 236-241.

Zou, F. S., Xiaojun, S., Haisheng, J., 1999a, Types and Characteristics of the Wetland of Hainan Island. TROPICAL GEOGRAPHY, 19(3), pp. 204-207. 